\title{
The effects of social isolation with motor restraint on a figure placement task
}

DAVID G, MARTIN and DAVID SCHROEDER, liniversity of Iowa. Jowa City. lowa 52240

Twenty-six Ss were restrained motorically before completing a figure-placement task measuring approach for human interaction. A similar group of control Ss engaged in mild motor behatior before doing the figure placements. Restrained Ss indicat'd more approach for interaction by placing figures closer together $(p<.025)$. Group differences diminished over trials as the effects of the experimental treatment diminished $(p<.001)$.

Gewirtz \& Baer (1958a, b) have presented evidence for the claim that brief "social isolation" increases the effectiveness of social reinforcers. They proposed that social isolation motivates behavior for social reinforcement by arousing a "social drive." Stevenson \& Odom (1962) argued that social isolation involves more general stimulus deprivation and non-social stimuli might serve to reduce the "social drive" aroused by isolation. Their results, however. supported Gewirtz and Baer: socially isolated Ss were more affected by social reinforcement than were controls, even when non-social stimuli were available. Social deprivation seems to arouse an approach tendency for social reinforcement. Previous studies, however, have utilized a social deprivation condition which included physical immobility (sitting in a waiting room) for all deprived Ss. Studies of inkblot perception after periods of immobility have reported increases in both activity and human content in Ss' responses (Meltzoff, Singer, \& Korchin. 1953; Singer, Meltzoff, \& Goldman, 1952; Singer \& Spohn, 1954). These results suggest the possibility that motor immobility might contribute to the arousal of the "social drive" previously attributed only to social isolation. The purpose of the present study was to demonstrate that, with social isolation held constant, motor restraint would enhance Ss' approach tendencies for human interaction.

As an approach to measuring "social schemata," the task of placing cut-out figures on a background has received considerable attention (Kuethe, 1962a, b). Using variations of the figure placement task, several investigators have presented correlational evidence that the horizontal distance between figures placed is a measure of approach or avoidance for human interaction (Weinstein, 1965; Levinger \& Gunner, 1967; Kuethe, 1964; Carlson \& Price, 1966). Martin \& Van Dyke (1968) have presented experimental evidence indicating that an elicited avoidance response will result in greater horizontal distance between figures. Their study also suggested the possibility that displacement of desired responses to the figure placement task might be the mechanism underlying the results reported with the horizontal distance measure.

In the present study it was predicted that a brief period of motor restraint would result in closer placements of figures in a figure placement task (greater approach for interaction). It was further predicted that the differences between experimental and control Ss would diminish over figure placement trials, as the effect of motor restraint diminished after treatment.

\section{SUBJECTS}

Fifty-two undergraduate students ( 26 males, 26 females) in an elementary psychology course served as Ss. Equal numbers of each sex were randomly assigned to the motor restraint or the control condition.

\section{PROCEDURES}

In the motor restraint condition. Ss were loosely tied in a padded office arm chair and were instructed not to move for 20 min. During the restraint period $E$ left the room but sat in an adjacent room where he could observe $S$ but could not be seen by S. Control Ss were also "socially isolated" in that E left the room while S performed a "picture rating" task in which he rated a set of pictures along a number of dimensions. This cover task was designed so that doing the ratings required $S$ to be engaged in mild motor activity for $20 \mathrm{~min}$ : the pictures were spread out around the room and Ss had to stand and walk throughout the procedure.

Following the treatment condition. all Ss were seated at a table facing $E$ and asked to complete a figure placement task designed by Martin (1967). The $S$ was presented with an 8-1/2 in. $x 11$ in. background scene containing no human figures (e.g.. living room, classroom, open field. etc.) and a set of cut-out cardboard figures. He was instructed to choose three of the figures and place them on the background to "make a picture that tells a story." The E recorded the positions of the figures and then presented the next trial with a different background. Each $S$ completed 10 such trials.

Upon completion of data collection, each picture was reconstructed from E's records and the average horizontal distance between pairs of figures was measured in inches.

\section{RESULTS}

The design used was a Type III analysis of variance following Lindquist (1956). Sex and treatment conditions were the between-Ss factors and trials was the within-Ss factor.

Figure 1 presents means over trials for the two treatment groups. The first hypothesis, that experimental Ss would place figures closer together than control $\mathrm{Ss}$ was supported $(F=7.24$, $\mathrm{df}=1 / 48, \mathrm{p}<.025)$. A significant interaction between experimental treatments and trials supported the second prediction, that the effects of the treatment would diminish over trials $(F=4.21$, $\mathrm{df}=9 / 432, \mathrm{p}<.001)$

Sex of $\mathrm{S}$ was not a significant variable, although a Sex by Treatment interaction approached significant $(F=2.80, \mathrm{df}=1 / 48$, $p<.10$ ). Visual inspection of the data indicated that this trend resulted from the fact that male Ss tended more clearly to perform in accordance with the hypotheses than female Ss.

\section{DISCUSSION}

The positive results for both hypotheses in the present study support the position that. with brief social isolation, further stimulus restriction increases Ss' tendency to approach human interaction. A question left unanswered by the design of this study is whether similar results would be obtained by restricting motor behavior only-by eliminating the social isolation.

The finding that differences between treatment groups diminished over trials seems to indicate that the effects of the treatment were shortlived. Treatment effects were expected to diminish during the figure-placement phase since Ss were returned to both social interaction (with E) and motor behavior (placing the figures). That the effects were of brief duration is not surprising, since the treatment lasted only $20 \mathrm{~min}$. A further question of interest is whether longer periods of restriction would result in longer lasting effects. If this inicrease in the duration of effects were found it should be determined whether it would reach an asymptote beyond which further restriction would have no effect.

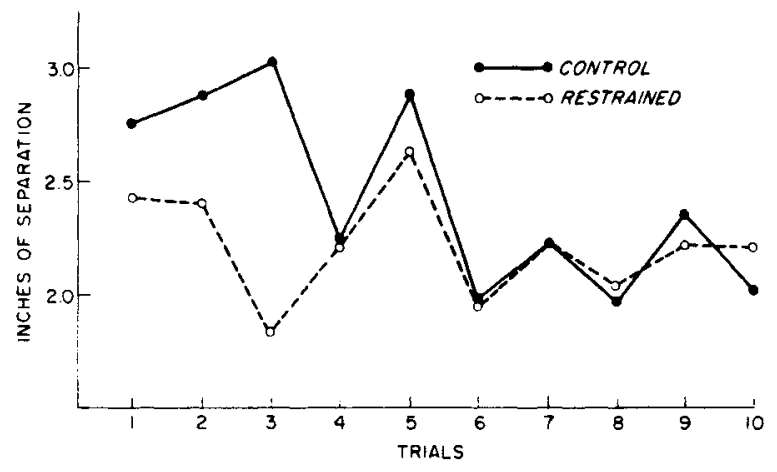

Fig. 1. Mean distances between figure pairs over trials. 


\section{REFERENCES}

CARLSON, R.. \& PRICE, M. A. Generality of social schenıs. Journal of Personality \& Social Psychology, 1966, 3, 589.592.

GEWIRTZ, J. L., \& BAER, D. M. The effect of brief social deprivation on behaviors for a social reinforcer. Journal of Abnormal \& Social Psychology, $1958,56,49-50$.

GEWIRTZ, J. L., \& BAER, D. M. Deprivation and satiation of social reinforcers as drive states. Journal of Abnormal \& Social Psychology, 1958. $57,165-172$

KUETHE, J. L. Social schemas. Journal of Abnormal \& Social Psychology, $1962 a, 64,31-38$

KUETHE, J. L. Social schemas and the reconstruction of social object displays from memory. Journal of Abnormal \& Social Psychology, 1962b, $65,71-74$.

KUETHE, J. L. The pervasive influence of social schemata. Joumal of Abnormal \& Social Psychology. 1964, 68, 248-254.

LEVINGER, G., \& GUNNER, J. The interpersonal grid: 1. Felt and tape techniques for the measurement of social relationships. Psychonomic
Science, $1967,8,173-174$.

LINDQUIST, E. F. Design and analy'sis of experiments in psychology and education. Boston: Houghton Mifflin Company, 1956.

MARTIN, D. G. The non-verbal picture assembly a figure placement task. Privately printed, 1967.

MARTIN, D. G., \& VAN DYKE, W. K. The expression of social experience in a figure placement task. Psychonomic Science, 1968, 12, 355-356.

MELTZOFF, J., SINGER, J. L., \& KORCHIN. S. Motor inhibition and Rorschach movement responses: A test of sensory-tonic theory. Journal of Personality, 1953, 21, 400-410.

SINGER, J. L., MELTZOFF, J., \& GOLDMAN, G. D. Rorschach movement responses following motor inhibition and hyperactivity. Joumal of Consulting Psychology, 1952, 16, 359-364.

SINGER, J. L., \& SPOHN, H. Some behavioral correlates or Rorschach's experience type. Journal of Consulting Psychology, 1954, 18, 1-9.

STEVENSON, H. W., \& ODOM, R. D. The effectiveness of social reinforcement following two conditions of social deprivation. Journal of Abnormal \& Social Psychology, 1962, 65, 429431. 